\title{
A 'new' DR4 associated D specificity 'JA' in Type 1 (insulin-dependent) diabetes: A9, Bw16, DJA, DR4 haplotype
}

\author{
A. Mustonen, J. Ilonen, H.-M.Surcel and H. K. Åkerblom \\ Department of Paediatrics, University of Oulu, National Public Health Institute, Oulu, and the Children's Hospital, \\ University of Helsinki, Helsinki, Finland
}

\begin{abstract}
Summary. The HLA antigen combination A9, Bw16 has been found to be associated with Type 1 (insulin-dependent) diabetes characterized by some special features in Northern Finland. This antigen combination has now been associated with a 'new' DR4-associated D antigen, provisionally called 'JA' or 'SN'. This 'new' D specificity was also associated with HLAB18. Although the combination, Dw3/DJA, was common in
\end{abstract}

Type 1 diabetic patients, the frequency of the combination Dw4/DJA was decreased compared with the expected value. This supports the hypothesis of two different risk factors associated with DR3 and DR4.

Key words: Type 1 diabetes, children, HLA, DR4 associated specificity ('JA').
In Northern Finland, Type 1 diabetes is strongly associated with HLA-B8/Dw3 and B15/Dw4 antigens [1], as is usual in Northern Europe [2], except that in Northern Finland, there is also an increased frequency of A9, Bw16 among patients with Type 1 diabetes. These antigens (more specifically Aw24 and Bw39) are in strong linkage disequilibrium in Finnish and most other Caucasoid populations [3]. The A9, Bw16 antigen combination was found to be particularly associated with familial cases of Type 1 diabetes [4], and patients with these antigens were characterized by either the absence or a short duration of detectable islet cell antibodies [5]. This haplotype was not associated with either Dw3 or Dw4, but with a 'blank' D-allele. Further, the patients with this $\mathrm{A} 9, \mathrm{Bw} 16, \mathrm{D}(-)$-combination and also patients with the Dw3/Dw4 combination had an earlier age of onset of diabetes compared with other patients [6]. We now describe a 'new' HLA-D specificity associated with this antigen combination and with DR4.

\section{Subjects and methods}

\section{Patients}

HLA typing results of 161 Type 1 diabetic patients from the Departments of Paediatrics from four university hospitals in Finland (Oulu, Tampere, Helsinki and Kuopio) have been used.

\section{Control subjects}

Healthy laboratory personnel and blood donors from the city of Oulu were used as the control group together with a study group of rubella sero-negative mothers and students who were found to have no differences in their HLA frequencies compared with normal subjects. The total number of control subjects was 89 .

\section{HLA-typing}

HLA-A, -B and -C antigens were determined by a two-stage microlymphocytotoxicity test [7]. HLA-D typing was carried out using local homozygous typing cells. The panel used consisted of two to four parallel cell preparations for the determination of Dw1-Dw5 and one cell preparation for Dw6 and the 'new' antigen, 'JA'. 'Doubly normalized' values accounting for variation of stimulating and responding cells were calculated according to Mendell et al. [8], and the antigen was considered to be present when the mean response to the cell typing for the specificity was below 50 .

HLA-DR typing was carried out from cell preparations depleted of $\mathrm{T}$ cells using 2-aminoethylisothiouriumbromide hydrobromidetreated sheep red blood cells [9]. Serum panels (purchased from the UCLA Tissue Typing Laboratory, Los Angeles, California, USA) were used according to the standard method with a $1-h$ incubation followed by $2-\mathrm{h}$ incubation with complement, after which eosin and formalin were added and trays read by phase contrast microscopy.

\section{Statistical analyses}

The $\chi^{2}$ test with Yates's correction was used in comparisons. Gene frequencies were calculated by the formula $p=1-\mathrm{VI}-\mathrm{a}$ where $\mathrm{a}$ is the phenotype frequency.

\section{Results}

One patient (JA) with Type 1 diabetes was found to have cells homozygous for the HLA-D-locus. The homozygosity of the A9, Bw16, C-, D- haplotype was 
Table 1. The association of ' $J A$ ' to HLA-A and -B antigens in patients with Type 1 diabetes

\begin{tabular}{|c|c|c|c|c|c|}
\hline \multirow[t]{2}{*}{$\begin{array}{l}\text { HLA } \\
\text { antigen }\end{array}$} & \multicolumn{2}{|c|}{$\begin{array}{l}\text { Patients } \\
\text { positive } \\
\text { for 'JA' } \\
(n=30)\end{array}$} & \multicolumn{2}{|c|}{$\begin{array}{l}\text { Patients } \\
\text { negative } \\
\text { for 'JA' } \\
(n=131)\end{array}$} & \multirow[t]{2}{*}{$p$} \\
\hline & No & $\%$ & No & $\%$ & \\
\hline A9 & 18 & 60 & 35 & 27 & $1 \times 10^{-3}$ \\
\hline Bw16 & 13 & 43 & 18 & 14 & $5.6 \times 10^{-4}$ \\
\hline B18 & 11 & 37 & 5 & 4 & $6 \times 10^{-8}$ \\
\hline B40 & 8 & 27 & 21 & 16 & NS \\
\hline
\end{tabular}

assured by a family study and both parents and siblings sharing the haplotype with the patient had a typing response against. 'JA' in mixed lymphocyte culture experiments. The segregation of the determinant defined by 'JA' with HLA haplotype A9, Bw16 was also observed in another diabetic family, and in a control family, segregation with the A2, B27, Cw2, DR4 haplotype was seen. No internationally recognised HLA-D specificity was found on cell ' $J A$ ' in experiments carried out at the Tissue Typing Laboratory of the State University Hospital, Copenhagen, but the cell was found to be DR4-positive. A Dw4/DR4 homozygous typing cell called SN [10] behaved similarly with 'JA' in most typing experiments, where both cells were included as typing reagents, and the cells were non-reactive against each other.

'JA' was found in 30 out of 161 Type 1 diabetic patients $(19 \%)$ and in 13 out of the 89 control subjects tested $(15 \%)$. The difference was not statistically significant.

The HLA-A and -B association of ' $J A$ ' in Type 1 diabetic patients is shown in Table 1 . In the Type 1 diabetic patients, the frequencies of $\mathrm{A} 9, \mathrm{Bw} 16$ and $\mathrm{B} 18$ were significantly increased among patients with 'JA'. B40 was also more common, although the difference was not significant. In the small group of 'JA'-positive control subjects, all these antigens were also more common than in 'JA'-negative patients, although B5, B12 and B27 were also found with increased frequency. Of the 16 patients with both $\mathrm{A} 9$ and $\mathrm{Bw} 16$ antigens, 12 (75\%) were positive for ' $\mathrm{JA}$ ', as was one control subject with this antigen combination. The combination of Dw3 and ' $\mathrm{JA}$ ' was found in 12 Type 1 diabetic patients, when the expected value calculated from phenotype frequencies was 6.07 $\left(\chi^{2}=5.79 ; p<0.05\right)$. On the other hand, the combination of Dw4 and 'JA' was rare; only two patients had this combination (expected value $10.30, \chi^{2}=6.69 ; p<$ 0.01 ).

HLA-DR typing was carried out in ten of the 'JA'-positive patients and in two 'JA'-positive control subjects. Nine of the patients and both control subjects were positive for DR4, indicating an association between these antigens. Linkage could be assumed on the basis that combinations of two strongly correlating $\mathrm{D}$ DR antigens were also found, namely Dw1/DR1 in both control subjects and Dw3/DR3 in three Type 1 diabetic patients.

\section{Discussion}

The organization of the HLA-region in the human major histocompatibility complex is still largely unknown and the relationship between $\mathrm{D}$ antigens determined by homozygous typing cells and DR antigens determined serologically by $\beta$-cell specific antisera remains unclear. The presence of corresponding major D and DR antigens is strongly correlated in Caucasoid populations, but DR4 is associated not only with Dw4 but also with a group of less well defined D-specificities which cover about one-third of DR4-positive subjects [10,11].

The first studies in which the D-locus association of Type 1 diabetes was established were carried out with homozygous typing cells [12]. Subsequent studies, including the Eighth Histocompatibility Workshop, have mainly been done with DR typing [13]. The association with DR3 and DR4 antigens has been revealed in several populations but only a few studies have been carried out with both cellular and serological methods. The study of Platz et al. [14] in a Danish population suggests that the DR4 association is the primary one.

We now describe the D/DR association of an HLA haplotype which we showed earlier to be associated with some specific characteristics of Type 1 diabetes. The earlier mentioned 'blank' allele of the D-locus is usually DJA-SN in the A9, Bw16 haplotype and is further associated with DR4. Thus, our results are in accordance with the findings of the Danish group, showing that DR4 is more strongly associated with Type 1 diabetes than is Dw4. Further, the comparisons of frequencies of $D$ antigens found in combination with ' $J A$ ' suggest that JA and Dw4 are associated with the same risk factor, because the combination of both does not appear with increased frequency. Most probably, this factor is DR4, or one strongly associated with it. The increase of Dw3 in combination with ' $J A^{\mathrm{A}}$ ' is clearly apparent, and this again supports the view of different risk factors associated with DR3 and DR4, showing increased disease risk when found together, whereas homozygosity for only one does not add to the risk over the heterozygous form.

In an earlier study, when we tried to localize the risk factor in the A9, Bw16 haplotype, we found that both of these antigens were risk factors, but only when associated with each other [4]. The present study suggests that DR4 is the risk factor associated with the haplotype and JA, perhaps, does not carry any additional risk. However, as A9, Bw16 was associated with specific features of the disease, it is still possible that the haplotype is associated with additional risk factors or disease course modifying factors. 'JA' was also found in association with B18 and perhaps with B40, both of which have been associated, in some populations, with increased 
risk of Type 1 diabetes, although not in the Finnish series. Both associations are currently considered to be secondary to DR associations, but the particular role of the B18-associated B1F1 allele has been a target of wide interest. We suggest that the search for HLA-associated heterogeneity within Type 1 diabetes should not be concentrated on only the strongest risk factors (DR3 and DR4), but that haplotype analysis should also be performed.

Acknowledgements. We thank Drs A. Svejgaard and M. Thomsen from the Tissue Typing Laboratory, State University Hospital, Copenhagen for help in characterizing the specificity of typing cell 'JA'. Drs A. Hakulinen and T.Huupponen are acknowledged for delivering blood specimens from their patients for HLA typing. The study was supported by the Foundation for Diabetes Research and Nordisk Insulinfond.

\section{References}

1. Ilonen J, Herva E, Tiilikainen A, Åkerblom HK, Mustonen A, Koivukangas T, Kouvalainen K (1980) HLA genetics of insulindependent diabetes mellitus in Northern Finland. Tissue Antigens 15: $381-388$

2. Cudworth AG, Wolf E (1982) The genetic susceptibility to Type 1 (insulin-dependent) diabetes mellitus. Clin Endocrinol Metabol 11: 389-408

3. Lokki M-L, Julin M (1982) HLA-A,B,C gene and haplotype frequencies in the Finnish population. Tissue Antigens 20:239-250

4. Ilonen J, Åkerblom HK, Tiilikainen A, Mustonen A, Herva E, Koskimies S, Kouvalainen K (1982) Increase of HLA haplotype A9-Bw16 in familial insulin-dependent diabetes mellitus in Northern Finland. Acta Diabet Lat 19: 167-174

5. Mustonen A, Ilonen J, Åkerblom HK, Tiilikainen A (1982) An islet cell antibody negative form of insulin-dependent diabetes mellitus associated with HLA antigens A9, Bw16. Clin Exp Immunol 48: $213-217$
6. Mustonen A, Ilonen J, Huupponen T, Åkerblom HK (1984) An association between age at onset and HLA risk antigens in insulindependent diabetes mellitus. Pediatr Res 18:112 (Abstract)

7. Turunen $O$, Lundquist $C$, Julin $M$, Holmlund G, Tiilikainen A, de la Chapelle A (1979) Stimulatory and cytotoxic activity on human adult and fetal lymphocytes by heterologous anti-human fetal lymphocyte sera. Transplant Proc 27: 304-308

8. Mendell NR, Guppy D, Bodmer WF, Festenstein H (1978) Joint report 3.2 (data management and assignment scores to MLC data). In: Bodmer WF, Batchelor JR, Bodmer JG, Festenstein H, Morris PJ (eds) Histocompatibility testing 1977. Munksgaard, Copenhagen, pp 90-114

9. Terasaki PI, Bernoco D, Park MS, Ozturk G, Iwaki Y (1978) Microdroplet testing for HLA-A, -B, $-\mathrm{C}$ and $-\mathrm{D}$ antigens. Am J Clin Pathol 69: 103-120

10. Thomsen M, Jakobsen BK, Kristensen T, Morling N, Platz P, Ryder LP, Svejgaard A (1983) Heterogeneity of HLA-D/DR4 defined by homozygous typing cells. Transplant Proc 15:123-125

11. Reinsmoen NL, Bach FH (1982) Five HLA-D clusters associated with HLA-DR4. Human Immunol 4: 249-258

12. Thomsen M, Platz P, Ortved Andersen O, Christy M, Lyngsoe J, Nerup J, Rasmussen K, Ryder LP, Staub Nielsen LP, Svejgaard A (1975) MLC typing in juvenile diabetes mellitus and idiopathic Addison's disease. Transplant Rev 22: 125-147

13. Svejgaard A, Platz PP, Ryder LP (1980) Joint report: insulin-dependent diabetes mellitus. In: Terasaki PI (ed) Histocompatibility testing 1980, University of California, Los Angeles, California, pp 638-656

14. Platz P, Jakobsen BK, Morling N, Ryder LP, Svejgaard A, Thomsen M, Christy M, Kromann H, Benn J, Nerup J, Green A, Hauge M (1981) HLA-D and -DR antigens in genetic analysis of insulindependent diabetes mellitus. Diabetologia 21: 108-115

Dr. A. Mustonen

Department of Paediatrics

University of Oulu

SF-90220 Oulu 22

Finland 